\title{
Strukturální fondy Evropské unie
}

\author{
Petra Beranová ${ }^{l}$
}

\section{I. Úvod}

Česká republika vstoupila do Evropské unie a tím získala možnost čerpání finančních prostředků z fondů Evropské unie. Dne 18. prosince 2003 byla úspěšně uzavřena jednání o strategii pro implementaci strukturálních fondů v České republice pro zkrácené programové období 2004-2006. Česká republika má možnost čerpat v prvních třech letech členství v Evropské unii až 1,525 mld. eur z prostředků EU. Přijatá strategie je v České republice implementována pomocí pěti operačních programů a Jednotných programových dokumentů pro region Prahy (pro Cíl 2 a pro Cíl 3).

Cílem tohoto příspěvku je seznámit s principy regionální a strukturální politiky Evropské unie, poskytnout základní informace o systému čerpání prostředků ze strukturálních fondů a posílit tak schopnost ČR využívat podpory strukturálních fondů Evropské unie.

\section{Hospodářrská a sociální soudržnost Evropské unie}

Jedním z úkolů Společenství je podpora hospodářské a sociální soudržnosti a tedy harmonický rozvoj Společenství jako celku. Tato povinnost Společenství je upravena v článcích 158-162 Smlouvy o Evropském společenství (součástí Smlouvy o Evropském společenství (dále též „Smlouva o ES“) se staly v roce 1987 v důsledku přijetí Jednotného evropského aktu). V preambuli Amsterodamské smlouvy se hovoří o solidaritě mezi národy Evropské unie (dále též „EU“), o jejich hospodářském a sociálním pokroku a o posilování soudržnosti.

V článku 158 Smlouvy o ES je zakotvena klauzule, že "Společenství usiluje zejména o snižování rozdílů mezi úrovněmi rozvoje rüzných regionů a o zmírňování zaostalosti regionů, které jsou v nejméně výhodné situaci včetně venkovských oblastī", v článku 159 se pak uvádí, že "Společenství podporuje dosažení těchto cílů prostřednictvím strukturálních fondü" a v článku 161 Smlouvy o ES je pak uveden vznik Fondu soudržnosti (uváděn také jako Kohezní fond). S politikou hospodářské a sociální soudržnosti mající prưřezový charakter samozřejmě souvisí i ostatní společné politiky Společenství. V praxi se zejména jedná o oblast společných pravidel pro soutěž (hlava VI. Smlouvy o ES), např. čl. 87 (podpory poskytované státy - na oblasti Cíle 1 strukturálních fondů se vztahuje odst. 3 písm. a/ tohoto článku), finanční ustanovení (články 268 až 280 Smlouvy o ES), která vymezují rozpočtové záležitosti Společenství, články 174 až 176 Smlouvy o ES upravující oblast životního prostředí, Protokol o Hospodářském a sociálním výboru a Výboru regionů atd. Opatření, která se vztahují k různým aspektům realizace strukturální politiky jsou dále zakotvena v nařízeních Rady a Komise Evropských společenství ke strukturálním fondům a Fondu

1 Ing. Petra Beranová, Institut integrace ČR do evropské a světové ekonomiky Fakulty mezinárodních vztahů Vysoké školy ekonomické v Praze. 
soudržnosti, která jsou v členských státech účinná přímo a která proto nejsou předmětem transpozice do národních legislativ; pouze je třeba vytvořit podmínky k jejich využívání.

Společenství si stanoví za cíl zejména snižovat rozdíly stavu rozvoje různých regionů a zaostalost nejvíce znevýhodněných území, včetně venkova. Aby tohoto cíle bylo dosaženo, Evropské společenství tyto cíle podporuje prostřednictvím strukturálních fondů, Evropské investiční banky a dalších nástrojủ. Úloha Společenství se však neomezuje pouze na finanční př́íspěvky. Prostřednictvím regionální politiky uplatňuje Společenství své vlastní pojetí rozvojových snah plánovaných na místní úrovni a doplňuje tak, v případě potřeby, pưsobení vnitřního trhu a hospodářské a měnové unie.

Výše uvedené cíle jsou pro členské státy závazné. Členské státy Evropské unie jim musí přizpůsobovat své hospodářské politiky a za tím účelem je navzájem koordinovat. Strukturální a regionální politické cíle obsažené v čl. 158 Smlouvy o ES musí být při stanovení a provádění všech ostatních politik Společenství respektovány.

Strukturální a regionální politika obecně zaujímá jedno z dominantních postavení v rámci celkové hospodářské politiky Evropské unie i v rámci její celkové politiky. To lze doložit např. výší finančních prostředkủ, vynakládaných na zabezpečení cílů regionální a strukturální politiky, čímž se dlouhodobě řadí na druhé místo hned za agrární politiku. $\mathrm{V}$ posledních letech se regionální politika podílí více než $35 \%$ na rozpočtových výdajích EU. Důvodem poměrně rozsáhlé strukturální politiky EU je skutečnost, že mezi jednotlivými regiony (dokonce mezi jednotlivými zeměmi EU) existují poměrně významné rozdíly, měřené například velikostí hrubého domácího produktu na obyvatele. Tyto rozdíly nezřídka vedou k tomu, že dochází k odlivu osob, kapitálu atd. z chudších regionů do bohatších, čímž se rozdíly dále prohlubují. V praxi tak nemají všichni občané stejnou příležitost využívat výhody společného trhu.

Strukturální a regionální politika Evropské unie se snaží dané rozdíly odstranit. Je nutno přiznat, že se jí to ne vždy daří. Příkladem země, kde pomoc prostřednictvím strukturálních fondů do značné míry napomohla tamnímu ekonomickému růstu, je Irsko, příkladem země, ve které i relativně masivní pomoc nevedla k výraznému odstranění rozdílů a zaostávání, může být Řecko.

Strukturální fondy přispívají ke snižování regionálních rozdílů a ke zlepšování životního prostředí, různou měrou se podílejí na výstavbě infrastruktury, podpoře výrobního a podnikatelského prostředí a investování do lidských zdrojů. Jejich význam je pro hospodářskou a sociální soudržnost v rámci EU nezastupitelný.

\section{Principy strukturální politiky}

Strukturální politika a v podstatě i využívání strukturálních fondů vychází z několika základních (operačních) principů:

\section{Princip koncentrace}

Je to vlastně zásada koncentrace úsilí, která spočívá $\mathrm{v}$ tom, aby prostředky fondů byly využívány pouze $\mathrm{k}$ realizaci předem stanovených cílů, co nejúčelněji a nebyly rozmělňovány na řadu drobnějších a méně významnějších akcí. Jde o snahu věnovat největší prostředky do regionů s největšími problémy, pokud možno na projekty přinášející maximální užitek. 


\section{2. $\quad$ Princip partnerství}

Zahrnuje úzkou spolupráci mezi Komisí a odpovídajícími orgány na národní, regionální a místní úrovni určenými každým členským státem pro všechny etapy programů. Jde o to, aby se na konkrétním rozdělení podíleli samotní př́ijemci, tj. regiony, města, obce i soukromé subjekty, pro něž jsou prostředky určeny.

\section{Princip programování}

Programování je tř̌etím hlavním operačním principem strukturálních fondů. Podává časový rozvrh pro alokaci pomoci. Prostředky fondů jsou alokovány na základě víceletých (plánovací období EU trvá 6 let) a víceoborových programů, nikoliv na základě jednotlivých projektů. Klade se důraz na komplexní př́ístup $\mathrm{k}$ řešení problémů př́ślušných regionů. Na realizaci konkrétního programu se $\mathrm{v}$ souladu s principem koncentrace podle potřeby podílí všechny strukturální fondy. S ohledem na zajištění kontinuity spolufinancování opatření strukturálních fondů po celé plánovací období EU vytváří víceletý př́istup požadavky i na př́ípravu veřejných rozpočtů.

\section{Princip adicionality (doplňkovosti)}

Uvedený operační princip strukturálních fondů směřuje k zajištění toho, že financování z fondů Společenství se nevyužije jako náhrada národních strukturálních subvencí. Prostředky ze strukturálních fondů EU pouze doplňují výdaje členských států. Členské státy musí poskytnout finanční informace potřebné $\mathrm{k}$ ověření adicionality při vytváření plánů a pak pravidelně během poskytování pomoci, přičemž nesmí v důsledku podpory ze strukturálních fondů sníziit vlastní výdaje, např. nelze snížit ve státním rozpočtu výdaje na dopravní infrastrukturu v důsledku podpory tohoto okruhu investic z EU.

\section{Princip monitorovánía vyhodnocování}

Jde o průběžné sledování a vyhodnocování prováděných opatření a celkové efektivnosti vynakládaných prostředků. Před schválením projektu je vyžadováno podrobné hodnocení jeho dopadů, pak následuje průběžné monitorování realizace projektu a nakonec zhodnocení skutečných přínosů projektu.

\section{Charakteristika strukturálních fondů}

Politika hospodářské a sociální soudržnosti EU spočívá v poskytování finančních stimulů a pobídek a koordinaci politiky členských států. Klíčovým nástrojem financování politiky hospodářské a sociální soudržnosti jsou strukturální fondy, ostatní finanční nástroje realizace strukturální politiky (Fond soudržnosti) a půjčky Evropské investiční banky a dalších finančních institucí.

V současné době jsou pro podporu opatření regionální a strukturální politiky používány tzv. strukturální fondy. Zaměření pomoci z každého fondu je stanoveno nařízeními Rady:

Evropský fond regionálního rozvoje - ERDF, rozvoj infrastruktury a podpora výrobních investic v méně prosperujících regionech, zejm.:

- investice do výroby určené k nárůstu nebo zachování stálých pracovních míst; 
- investice do infrastruktury včetně transevropských sítí pro regiony zařazené do Cíle 1;

- investice do vzdělání a zdraví pro regiony zařazené do Cíle 1;

- rozvoj domácího potenciálu: místní rozvoj a rozvoj malého a středního podnikání v problémových regionech;

- výzkum a rozvoj;

- investice zaměřené na životní prostředí.

Evropský sociální fond - ESF, podpora zaměstnanosti, především programy kvalifikační a rekvalifikační, vytváření nových pracovních míst:

- integrace nezaměstnaných zaměřená na dlouhodobou nezaměstnanost;

- integrace mladých lidí do pracovního procesu podle výzkumu nezaměstnanosti;

- integrace osob vyloučených z trhu práce;

- podpora stejných př́ležitostí na trhu práce;

- adaptace pracovníků na průmyslové změny;

- stabilizace a růst zaměstnanosti;

- posílení lidského potenciálu ve výzkumu, vědě a technologii;

- posílení systému vzdělávání a další kvalifikace.

Podpůrná sekce Evropského zemědělského usměrňovacího a záručního fondu EAGGF-G, podpora adaptace zemědělských struktur a rozvoje venkova:

- podpora př́ijmu farmaření a zachování životaschopných farmářských komunit v horách nebo méně příznivých oblastech;

- startovací podpora pro mladé farmáře;

- zlepšení strukturální výkonnosti držby půdy;

- podpora ustanovení producentských asociací;

- konverze, diverzifikace, reorientace a podpora kvality zemědělské produkce;

- rozvoj venkovské infrastruktury;

- podpora investic do cestovního ruchu;

- ostatní opatření jako jsou prevence př́rodních pohrom, obnova vesnic, ochrana venkovského (kulturního) dědictví, rozvoj a využití lesů, ochrana prostř̌edí a krajiny a finanční řízení.

Finanční nástroj pro podporu rybolovu - FIFG, podpora strukturální adaptace v rybářství:

- změny v rybářském sektoru;

- modernizace lod'stva;

- rozvoj chovu ryb;

- ochrana některých přímořských oblastí; 
- vybavení rybářských př́istavů;

- výroba a obchod s rybími výrobky;

- podpora výroby.

Uvedené strukturální fondy slouží k naplňování cílů strukturální a regionální politiky. Pro programovací období 2000 - 2006 stanovila Evropská komise tř̌i Cíle. Pro každý Cíl jsou určena kritéria, která musí region splňovat, aby byl zařazen pod daný Cíl. Každý Cíl znamená jinou úroveň pomoci:

Cíl 1: Podpora rozvoje a strukturálních změn zaostávajících regionů s větším důrazem na investice do výroby a trvale udržitelný rozvoj. Jedná se o regiony s HDP na hlavu nižším než je $75 \%$ průměru EU. Intenzivnější pomoc by měla vycházet z velikosti populace, rozdílů mezi regionálním bohatstvím a průměrem EU a z národního bohatství. Dodatečná podpora je poskytována regionům s velmi vysokou nezaměstnaností. Regiony s velmi nízkou hustotou obyvatelstva by měly mít speciální dohody. O zvláštní situaci velmi odlehlých regionů (ve Finsku a Švédsku, francouzské zámořské departmenty, Kanárské ostrovy, Azory a Madeira) se v programovém období 2000-2006 jedná v rámci Cíle 1. Strukturální fondy mohou financovat až $75 \%$ celkových nákladů na projekty spadající pod Cíl 1 .

Jde přibližně o padesát regionů, které jsou domovem $22 \%$ obyvatel EU. Do těchto regionů se investuje $69,7 \%$ dostupných prostředků.

Cíl 2: Potřeba větší ekonomické a sociální restrukturalizace oblastí postižených změnami v průmyslu, službách nebo v rybářství, venkovské oblasti ve vážném úpadku a městské oblasti v potížích. Geografická koncentrace v nejvíce postižených oblastech a rozsah pomoci jak shodný tak možný s oblastmi, kterým pomáhají členské státy. Podobně jako u Cíle 1 intervence Unie pro oblasti spadající pod Cíl 2 je kombinována se všemi formami strukturální podpory, včetně opatření směřujících k lidským zdrojům. Strukturální fondy mohou financovat až $50 \%$ celkových nákladů na projekt.

$\mathrm{V}$ těchto regionech zasažených krizí žije $18 \%$ obyvatelstva EU. Směřuje sem $11,5 \%$ celkového objemu prostředků ze strukturálních fondů.

Cíl 3: Podpora adaptace a modernizace systému vzdělávání, vzdělávacích programů a zaměstnanosti. Determinovaná nabídka by měla pomoci modernizovat pracovní trhy v souladu s mnohaletými plány pro zaměstnanost a s novou kapitolou o zaměstnanosti uvedenou v Amsterodamské smlouvě. Evropský sociální fond může financovat až $50 \%$ celkových nákladů na projekt.

Cíl 3 by měl podporovat aktivity v těchto oblastech:

- $\quad$ spojení hospodářských a sociálních změn;

- dlouhodobé vzdělání a vzdělávací systémy;

- aktivní politika v oblasti trhu práce, jako je boj proti nezaměstnanosti;

- boj se sociální diskriminací.

Hlavní sociální skupiny spadající pod Cíl 3 tvoří mladí lidé, dlouhodobě nezaměstnaní, lidé zasažení sociální exkluzí (vyloučením ze společnosti) a nekvalifikovaní pracovníci. Nemusí přitom jít o lidi žijící v zaostávajícím regionu nebo v oblasti, kde probíhá konverze; pomoci se jim mủže dostávat kdekoli v EU. 
Na realizaci Cíle 3 se vynakládá 12,3\% celkových prostředků.

\section{Formy pomoci ze strukturálních fondů}

Formy pomoci financované strukturálními fondy lze rozdělit do tří kategorií:

- pomoc vázaná na iniciativu členských států (cca 93,8\% celkové částky), která je koncipována na základě rozvojových plánů předložených členskými státy nebo regiony;

- pomoc vázaná na "samostatné" iniciativy Společenství (5,35 \% celkové částky), kterou poskytuje Komise Evropských společenství z vytvořených specifických zdrojů přístupných pro opatření zvláštního zájmu Společenství;

- inovační postupy a opatření ( 0,65 \% celkové částky) jsou také vázány na iniciativu Komise. I tyto se soustřed’ujńa zkoumání nových způsobů dosažení cílů strukturální a regionální politiky.

Existují rovněž zvláštní příděly prostředků na úpravu struktury rybolovu mimo regiony spadající pod Cíl $1(0,5 \%)$.

\section{Iniciativy Společenství}

Iniciativy Společenství se zaměřují na financování inovativních a pilotních projektů s důrazem na partnerskou mezinárodní a meziregionální spolupráci. V současné době existují čtyři Iniciativy Společenství s cílem najít obecné řešení problémů postihujících Unii jako celek. Každou z iniciativ Společenství financuje pouze jeden fond:

- Interreg III přeshraniční, transnacionální a meziregionální spolupráce (financován $\mathrm{ERDF})^{2}$;

- Leader + poskytuje podporu pilotním, integrovaným strategiím pro rozvoj venkovských oblastí, podpora spolupráce mezi venkovskými oblastmi (financován EAGGF-G) ${ }^{3}$;

- Urban II hospodářská a společenská obnova krizových zón ve městech a příměstských (venkovských) oblastech (financován ERDF);

- Equal eliminace faktorů vedoucích $\mathrm{k}$ nerovnosti a diskriminaci v př́stupu na trh pracovních sil (financován ESF) ${ }^{4}$.

2 Program INTERREG III je jednou z iniciativ Evropských společenství, do níž se po svém př́stupu k Evropské unii začlení rovněž Česká republika. Program INTERREG III se dále dělí na tyto části: INTERREG IIIA - rozvoj přeshraniční spolupráce jako základ podpory vnitřních a vnějššch pohraničních oblastí Unie při překonávání problémů plynoucích z izolovanosti. $\mathrm{V}$ př́íhraničních oblastech INTERREG IIIA bezprostř̌edně navazuje na předvstupní program Phare CBC. INTERREG IIIB - rozvoj mezinárodní spolupráce a INTERREG IIIC - rozvoj spolupráce mezi regiony.

3 Iniciativa Společenství LEADER + nebude v plánovacím období 2004-2006 otevřena jako samostatný finanční zdroj, ale aktivity typu LEADER + budou začleněny v rámci Operačního programu Rozvoj venkova a multifunkční zemědělství. Implementace LEADER + bude zaměřena na Oblast 1 Iniciativy LEADER+ Strategie pilotního charakteru pro integrovaný rozvoj venkovských oblastí.

4 Česká republika se zapojí do iniciativy EQUAL (II. kolo). Podporovány budou následující priority: Zlepšování zaměstnatelnosti (Priorita 1), Rozvoj podnikání (Priorita 2), Podpora adaptability (Priorita 3), Rovné př́ležitosti mužủ a žen (Priorita 4), Pomoc žadatelům o azyl v př́ístupu na trh práce (Priorita 5) a Technická asistence programu iniciativy Společenství EQUAL. 
Pro programové období 2004 - 2006 budou pro Českou republiku otevřeny pouze iniciativy Interreg III a Equal.

\section{Inovační postupy a opatření}

Vedle národních programů a programů Iniciativ Společenství financují strukturální fondy také studie, opatření technické pomoci a pilotní projekty vztahující se k jejich druhům činnosti.

Pro Evropský fond regionálního rozvoje byla určena tři témata:

- regionální ekonomická inovace (založená na znalostech a technologických inovacích);

- e-EuropeRegio: informační společnost ve službách regionálního rozvoje;

- regionální identita a trvale udržitelný rozvoj.

Další inovační opatření jsou plánována pro oblast zaměstnanosti a vzdělávání (financováno ESF) a pro oblast rybolovu (financováno FIFG).

V rámci těchto programů se financují práce na nových strategiích a zajištujese realizace experimentální fáze jednotlivých projektů. Když počáteční fáze přinese uspokojivé výsledky, lze projekt zařadit do strategií pro jednotlivé prioritní Cíle.

Pilotní a/nebo vzorové projekty mohou být předkládány členskými státy, regionálními nebo místními orgány nebo soukromými osobami.

\section{Pojmosloví strukturální a regionální politiky}

Současná strukturální a regionální politika EU vychází z principu programování (plánování), který je postaven na povinnosti zpracovávat víceleté rozvojové programy. Jde v zásadě o princip, že ze strukturálních fondů se nepřispívá na financování jednotlivých akcí, ale na podporu rozvojových programů, jež mají svůj vlastní rozpočet členěný podle priorit, subprogramů a jednotlivých opatření. Struktura těchto programů zahrnuje analýzu území včetně určení slabých a silných stránek a formulování celkové strategie rozvoje území. V rozvojových programech jsou vymezeny nejdůležitější priority a cíle rozvoje oblasti a dále opatření a subprogramy vedoucí $\mathrm{k}$ naplnění priorit a $\mathrm{k}$ dosažení vytýčených cílù. $\mathrm{Na}$ tuto strategii pak navazuje podrobné rozpracování jednotlivých opatření včetně vymezení finančního rámce, tzn. prostředky EU, národní prostředky (státní, regionální, místní a další) a rovněž prostředky soukromého sektoru, dále splnění principu doplňkovosti a definování podmínek realizace programu.

Dalším ze základních principů využívání strukturálních fondů je princip programování. Členský stát EU musí v programových dokumentech předem stanovit a popsat rozvojové aktivity, které považuje za důležité pro financování v rámci regionální a strukturální politiky EU, a to před přidělením prostředků ze společného rozpočtu EU. Tímto způsobem by mělo být zajištěno, že podpora ze strukturálních fondů půjde do nejpotřebnějších oblastí a sektorů.

Pro každou zemi existuje Národní program, který je dále rozpracován do Regionálního rozvojového plánu na národní nebo regionální úrovni. Obecně platí, že členské státy Evropské unie připravují rozvojový plán vždy pro jeden nebo více regionů úrovně NUTS 
II ${ }^{5}$, která splňují kritéria zařazení pod Cíl 1 politiky hospodářské a sociální soudržnosti EU. V Regionálním rozvojovém plánu jsou analyzovány problémy a uvedena opatření, která pro zlepšení situace realizovala př́slušná vláda a výsledky, jichž bylo dosaženo v předchozích plánovacích obdobích. Dále jsou v něm obsaženy regionální rozvojové priority, včetně jejich kvantifikace, strategie na jejich dosažení, je uveden přehled subjektů, u nichž se předpokládá participace na implementaci projektů a rámcové finanční požadavky daného státu vycházející ze zásad pro poskytování podpor pro jednotlivé typy problémových regionů. Neopomenutelnou součástí regionálních rozvojových plánů je zhodnocení předpokládaných ekologických dopadů navrhované regionální strategie. Regionální rozvojový plán představuje zevrubné zdůvodnění potřeby podpor a definuje cíle, jichž má být dosaženo. Tento dokument předkládá př́slušná vláda Evropské komisi.

Podle používaného indikátoru, kterým je hrubý domácí produkt na obyvatele v paritě kupní síly, všechny regiony úrovně NUTS II v České republice (tzv. regiony soudržnosti) s výjimkou Prahy, která průměr EU vysoce převyšuje - dosahují méně než $75 \%$ průměru úrovně HDP na obyvatele Evropské unie. Region soudržnosti Praha bude způsobilý pro získání prostředků v rámci Cíle 2 a Cíle 3 . Na základě těchto faktů a s ohledem na doporučení Generálního ředitelství Evropské komise pro regionální politiku bylo rozhodnuto o zpracování uceleného programového dokumentu pro celý stát, proto hovoříme o Národním rozvojovém plánu Ceské republiku.

Hlavním souhrnem pro rozvoj je v rámci Národního rozvojového plánu Rámec podpory Společenství. Rámec podpory Společenství představuje dokument schválený Evropskou komisí po dohodě $\mathrm{s}$ prríslušným členským státem, a to na základě předloženého Regionálního rozvojového plánu, který obsahuje strategii a priority pro společné akce strukturálních fondů a členského státu, jejich specifické cíle, pokud možno kvalifikované, hodnocení očekávaného dopadu, hospodářskou politiku, strategii zaměstnanosti a rozvoje lidských zdrojů a regionální politiku členského státu. Rámec podpory Společenství je vlastně smlouvou mezi Komisí a vládou členského státu určující priority a formy podpory Společenství včetně rozsahu finančních prostředků a období, po které bude podpora poskytována. V Rámci podpory Společenství se vymezují tzv. Priority, kterým je určen příspěvek ze strukturálních fondů a soubor specifických cílů. Rámec podpory Společenství je realizován prostřednictvím jednoho nebo více operačních programů. Je nástrojem koordinace veškeré strukturální pomoci EU v př́ślušných regionech, včetně pomoci pro rozvoj lidských zdrojů.

Rámec podpory Společenství dále obsahuje orientační plán pro každou prioritu a rok, finanční alokace předpokládané pro příspěvek každého fondu, případně Evropské investiční banky, a ostatní finanční nástroje. Obsahuje rovněž opatření pro realizaci Rámce, včetně ustanovení řídícího orgánu, zodpovědného za řízení Rámce členským státem, opatření pro zapojení partnerů do monitorovacích výborů. Zahrnuje rovněž předběžné ověření adicionality a odpovídající informace o transparentnosti finančních toků, zejména od členského státu do regionů.

Pouze poté, kdy je tento rámcový dokument přijat členským státem a Evropskou komisí, mohou být schváleny konkrétní programy („operační a prováděcí“) sloužící k jeho realizaci. Orgány členského státu poté přebírají zodpovědnost za vypracování podrobnějších programových dodatků.

5 V Evropské unii se používá dělení na územní statistické jednotky, tzv. NUTS (z francouzského Nomenclature des Unités Territoriales Statistiques). Pro potřeby strukturální a regionální politiky jsou důležité tzv. NUTS II (kterých je v České republice osm a zhruba odpovídají území s 1 milionem obyvatel) a NUTS III (kterých je v České republice 14 - kraje/VÚSC). Takto definované územní jednotky mají přímou vazbu na čerpání prostředků ze strukturálních fondů. 
Na nižší úrovni (obvykle regionálního charakteru) rozpracování jsou Operační programy. Operační program je dokumentem sloužícím k realizaci schváleného Rámce podpory Společenství. Skládá se z konzistentního souboru priorit a zahrnuje víceletá opatření, která mohou být realizována prostřednictvím jednoho nebo více fondů, jednoho nebo několika různých finančních zdrojů a Evropské investiční banky. Operační program zahrnuje bližší specifikaci podpor, zajištění systému realizace a kontroly, včetně ustavení monitorovacích a řídících výborů, sekretariátů, poradních jednotek, stanovení nástrojů podpor. Obsahuje informace o směrech hlavních priorit, jejich souladu s prioritami Rámce podpory Společenství, jejich specifických cílech (vyčíslení) a předběžné hodnocení. Každá z priorit operačního programu by měla sdílet jedinou hlavní prioritu Rámce podpory Společenství. Každý operační program musí odpovídat výhledům a finančním možnostem, které se vztahují k regionálním příjemcům podpory. Celkové sumy všech operativních programů jak z hlediska prioritních směrů, tak z hlediska roků, musí odpovídat stejným hodnotám prioritních směrů a roků odpovídajících Rámci podpory Společenství.

Operační programy mohou být sektorové-odvětvové (celoplošné) nebo regionální, tj. pro každý region úrovně NUTS II. Operační program shrnuje rozvojový plán. Představuje žádost o podporu. Komise ES teprve na základě tohoto dokumentu přijme rozhodnutí o poskytnutí podpory. Po jeho schválení Evropskou komisí může konečně začít vlastní realizace konkrétních projektů.

Pro rozvoj území České republiky byly vypracovány následující operační programy:

a) sektorové:

- OP Průmysl a podnikání,

- OP Infrastruktura,

- OP Rozvoj lidských zdrojů,

- OP Rozvoj venkova a multifunkční zemědělství,

b) společný regionální operační program.

Jednotlivé operační programy podrobně popisují aktivity, které je možno financovat ze strukturálních fondů. Také zde se vyskytují priority daných sektorů či regionů a jsou strukturalizovány do jednotlivých opatření, které mají již své konkrétní operační cíle jako výstupy.

Na stejné úrovni jako Rámec podpory Společenství je Jednotný programový dokument schválený Evropskou komisí a obsahující stejnou strukturu jako Rámec podpory Společenství nebo operační program. Tento dokument předkládá př́slušná vláda. K němu Komise ES přijme tzv. závazné rozhodnutí.

Obecně platí, že pomoc poskytovaná podle Cíle 2 a Cíle 3 bude mít formu Jednotného programového dokumentu.

Cíl 1 pro regiony Cíle 1 je Jednotný programový dokument použiván jen výjimečně.

Cíl 2 dokument zabezpečuje koordinaci veškeré strukturální pomoci EU včetně koordinace rozvoje venkova, ale s vyloučením pomoci na rozvoj lidských zdrojů, poskytované podle Cíle 3 ve všech oblastech krytých Cílem 2.

Cíl 3 dokument zajiš̌luje koordinaci veškeré strukturální pomoci EU na rozvoj lidských zdrojů s výjimkou pomoci poskytované podle Cíle 2. 
Česká republika vypracovala dva jednotné programové dokumenty:

1. Jednotný programový dokument pro Cíl 2 regionu soudržnosti hl.m. Praha

2. Jednotný programový dokument pro Cíl 3 regionu soudržnosti hl.m. Praha

Každý Jednotný programový dokument je doplněn Programovým dodatkem. Programový dodatek (někdy též Programový doplněk) stanoví podmínky a postupy realizace - je podrobnějším a konkrétnějším dokumentem (poskytuje bližší informace $\mathrm{k}$ jednotlivým opatřením - typy možných projektů, kritéria výběru, konečné př́ijemce pomoci, finanční plán apod.). Dále obsahuje popis systému řízení, implementace, monitorování, kontroly a hodnocení operačních programů. Je zasílán pro informaci Evropské komisi. Programový dodatek je zpracováván rovněž pro jednotlivé operační programy. Podrobnější informace pak obsahují tzv. manuály.

Programové dokumenty jsou předkládány na základě iniciativy členského státu, přičemž při zpracování programových dokumentů musí být respektován princip programování, který má umožnit př́ípravu a realizaci provázaných multioborových programů a sladit jednotlivé dílčí kroky v různých sférách a vyhnout se tak neefektivním ad hoc přístupům; programování rovněž zaručuje jistou kontinuitu, a rovněž princip partnerství, který by měl zaručit, že si připravovaný program získá podporu subjektů, pro něž je zřízen anebo kterým je určen, čímž se zvyšují šance na jeho úspěšnou implementaci.

\section{Realizační postupy}

\section{Decentralizované rízení, kontrola a financování}

Evropská komise převádí finanční prostředky Evropské unie do členských států pouze tehdy, když skutečně dochází k realizaci rozvojových programů, které přijala. Komise podporuje zahájení nových programů tím, že po oficiálním schválení takového programu připíše na příslušné konto platbu ve výši $7 \%$. Ćlenské státy pak Komisi žádají o další platby, z nichž Komise hradí pouze ověřené a doložené výdaje odpovídající platbám provedeným konečnými př́ijemci a doloženými potvrzenými fakturami nebo účetními dokumenty rovnocenné důkazní hodnoty. Žádosti o průběžné platby by měly být Komisi předkládány hromadně třikrát za rok (poslední nejpozději 31. října). Souhrnný úhrn plateb, které se vyplatí na pomoc, nesmí překročit podíl $95 \% \mathrm{z}$ příspěvku z fondů na tuto pomoc.

Pro urychlení finančních procedur stanoví nařízení základní pravidla obsahující platební uzávěrky:

- Komise do dvou měsíců po schválení vynaložených výdajů pošle peníze členskému státu);

- platební orgán je poté povinen zajistit, že koneční př́ijemci obdrží platbu příspěvku z fondů v plné výši co nejrychleji.

Nařízení stanovují minimální a maximální podíly pomoci ze strukturálních fondů. Pro regiony zařazené do Cíle 1 finanční pomoc ze strukturálních fondů nesmí překročit $75 \%$ celkových přípustných nákladů a musí činit přinejmenším 50 \% veřejných výdajů na opatření. V rámci nařízení je specifikováno, že ve výjimečných a náležitě odůvodněných případech příspěvek ze strukturálních fondů regionům zařazeným do Cíle 1 ve čtyřech zemích zahrnutých do Fondu soudržnosti (Řecko, Irsko, Portugalsko, Španělsko) může dosáhnout maxima $80 \%$ celkové částky a maximálně $85 \%$ celkové částky pro vnější regiony stej- 
ně jako pro mimoležící řecké ostrovy, které jsou znevýhodněny svojí vzdáleností. Pro ostatní priority je horní mez na $50 \%$ celkových př́ípustných nákladů s minimem $25 \%$ veřejných výdajů na opatření. Tyto podíly se aplikují ve všech formách pomoci ze strukturálních fondů s výjimkou opatření technické pomoci konané z iniciativy Komise. Financování z Evropské unie pro posledně zmíněné může ve výjimečných a náležitě odůvodněných př́padech činit až $100 \%$ celkových nákladů. Pro potřebné srovnání postupu při platbě dotací s důrazem na přísnou účetní disciplínu stanovují nařízení rovněž systém závazků, hlavně v ročních splátkách, na základě rozhodnutí Komise, a systém plateb spojených se závazky. Platby mohou mít formu plateb na účet, průběžných plateb anebo proplacení závěrečné bilance.

Př́spěvky z fondů mají v zásadě formu dotace nebo jinou formu financování (např̀. zvýhodněné úvěry, subvencování úrokové sazby, účast rizikového kapitálu). Př́íspěvky z fondů podléhají následujícím omezením:

a) maximálně $75 \%$ z celkových př́ípustných nákladů projektů a zpravidla nejméně $50 \%$ způsobilých veřejných výdajů;

b) v případě investic do infrastruktury, z nichž se získá značný čistý výnos, nesmí př́íspěvek překročit $40 \%$ celkových př́ípustných nákladů, na než se vtahuje Cíl 1 ; s tím, že je možno tento podíl zvýšit o dalších $10 \%$ v členských státech, na něž se vztahuje Fond soudržnosti; př́íspěvek nesmí překročit $25 \%$ celkových přípustných nákladů v oblastech, na něž se vztahuje Cíl 2; tyto podíly lze zvýšit o určitou částku pro jiné formy financování, než je přímá pomoc za předpokladu, že toto zvýšení nepřekročí $10 \%$ z celkových př́ípustných nákladů;

c) v případě investic do firem nesmí příspěvek překročit $35 \%$ z celkových přípustných nákladů, na něž se vztahuje Cíl 1; př́íspěvek nesmí překročit $15 \%$ celkových př́ípustných nákladů $\mathrm{v}$ oblastech, na něž se vztahuje Cíl 2; s tím, že v případě investic do malých a středních podnikủ lze tyto podíly zvýšit maximálně o $10 \%$ celkových př́ípustných nákladů projektu v případě, že půjde o jinou podporu než přímou pomoc.

Dle Smlouvy o přistoupení k Evropské unii uzavřené mezi stávajícími členskými státy EU na straně jedné a novými členskými státy, tedy i Českou republikou, na straně druhé v Athénách dne 16. dubna 2003 (dále jen „Smlouva o přistoupeni“) jsou pro př́spěvek z fondů způsobilé (od 1. ledna 2004) výdaje spojené s jednotlivými projekty, jestliže splňují podmínky vyplývající z předpisů o strukturálních fondech a Fondu soudržnosti. Podmínky se týkají shody s legislativou Společenství v oblastech regionální politiky, zadávání veřejných zakázek, ochrany životního prostředí, finančního rrízení a kontroly, rovnosti příležitostí atd. Teoreticky by tak měly být pro příspěvek ze strukturálních fondů Evropské unie způsobilé výdaje spojené s jednotlivými projekty vynaložené již na počátku roku 2004. Vyskytují se však názory, že profinancovatelné jsou pouze ty výdaje, které vznikly až po schválení žádosti, resp. po podepsání smlouvy s př́ijemcem podpory.

Konečné datum způsobilosti výdaje se vztahuje k platbám provedeným konečnými př́ijemci, pokud budou provedeny do 31. prosince 2008 (podstatné náležitosti však musí být ukončeny do 31. prosince 2006).

Pro způsobilost výdajů jednotlivých vybraných projektů jsou, vedle vnitrostátních pravidel, plně respektována pravidla obsažená v nařízení Komise ES č. 448/2004, týkající se způsobilosti výdajů na činnosti spolufinancované fondy. 
V rámci realizace projektů financovaných prostřednictvím strukturálních fondů uzavírá řídící orgán dohodu o financování s konečným příjemcem (v případě, že je projekt realizován s využitím zprostředkujícího subjektu, musí rídící organ uzavř́ít se zprostředkujícím subjektem dohodu o delegování pravomocí a zprostředkující subjekt uzavřít dohodu s konečným př́ijemcem o financování projektu). Dohoda musí být jasná, přesná a úplná. Může být měněna formou písemných dodatků a nastanou-li změny týkající se finančních ustanovení, musí dodatek schválit řídící orgán.

Převod prostředků konečným př́ijemcům provádí platební jednotka daného operačního programu z čerpacího účtu do výše otevřeného limitu. Platby jsou konečným př́ijemcům převáděny v národní měně pouze na bankovní účet, který je specifikovaný v př́ślušné dohodě mezi řídícím orgánem, resp. zprostředkujícím subjektem a konečným př́ijemcem. Zálohy konečným příjemcům na financování projektu před započetím prací se v zásadě neposkytují. Ve zvlášézdůvodněných případech může platební orgán povolit poskytnutí zálohy, avšak musí to být schváleno platebním orgánem a upraveno v písemné dohodě mezi řídícím orgánem, resp. zprostředkujícím subjektem a konečným příjemcem. $V$ př́ípadě Evropského sociálního fondu je možné zásadu, že konečný př́ijemce musí nejdříve vše zaplatit a teprve poté žádat spolufinancování z Evropské unie, porušit, a to ve výjimečných případech, je-li konečným př́ijemcem nezisková organizace, která prokáže, že není schopna projekt předfinancovat. Této neziskové organizaci mohou být poskytovány zálohové platby z české strany spolufinancování projektů strukturální a regionální politiky EU.

Žádosti o provedení platby předkládá řídící orgán platební jednotce jednou měsíčně. Žádost musí být doložena požadovanými doklady, zejména př́íslušnými fakturami a osvědčením o provedené práci.

Všechny programové dokumenty schválené Komisí obsahují podrobná společná ustanovení pro finanční realizaci opatření. Pro každý program jmenuje členský stát řídící orgán, který je zodpovědný za výběr projektů, které se budou financovat. Platební orgán pak ověřuje výdaje a zabývá se žádostmi o proplácení, které se předkládají Komisi. Platební orgány musí zaručovat, že veškeré výdaje nárokující proplácení ze strukturálních fondů Evropské unie odpovídají platným kritériím a konkrétní politice Společenství - např. pro zajištování rovnosti př́ležitostí, pro poskytování státní pomoci a na ochranu životního prostředí. Zjistí-li Komise, že kontrola na národní úrovni je nedostačující, nebo zjistí-li př́ipadné nesrovnalosti, může zastavit výplaty požadovaných prostředkủ nebo i žádat vrácení již vyplacených částek.

\section{Soulad s politikami Společenství}

V souladu s čl. 12 nařízení Rady (ES) č. 1260/1999 jsou podporovány pouze takové aktivity, které jsou v souladu se Smlouvou o založení Evropského společenství, s nástroji přijatými v jejím rámci a s politikami a akcemi Společenství, včetně pravidel pro hospodářskou soutěž (veřejnou podporu), o zadávání veřejných zakázek, o ochraně a zlepšování životního prostředí (každý regionální Rámec podpory Společenství nebo Jednotný programový dokument obsahuje environmentální situaci v daném regionu a zhodnocení vlivu prostředí na navrhovanou strategii a opatření) a o odstraňování nerovností a vyrovnávání př́iležitostí mezi muži a ženami.

Všechny programové dokumenty schválené Komisí obsahují společná ustanovení, která detailně popisují principy, jež je nutno respektovat, aby byla zajištěna kompatibilita mezi opatřeními financovanými ze strukturálních fondů a ostatních zdrojů Evropské unie. 


\section{Minimum opatření pro publicitu}

Aby se informace o příležitostech nabízených strukturálními fondy dostaly k možným zájemcům a aby se pozvedlo povědomí veřejnosti o činnosti Evropské unie, vyžaduje komunitární legislativa po organizacích zodpovědných za realizaci opatření provádět adekvátní publicitu pomoci EU.

Evropská komise přijala v roce 2000 nařízení Komise (ES) č. 1159/2000 o informačních a propagačních opatřeních prováděných členskými státy v souvislosti s pomocí ze strukturálních fondů, popisující podrobně zodpovědnost a opatření vztahující se k minimu publicity.

Pravidla jsou určena pro zajištění větší transparentnosti pomoci pro potenciální vykonavatele (př́ijemce dotací) opatření financovaných strukturálními fondy a větší viditelnosti příspěvkủ Evropské unie v projektech určených široké veřejnosti. Tato opatření zahrnují:

- billboardy zmiňující pomoc Evropské unie tam, kde je spolufinancována ze strukturálních fondů;

- pamětní desky (plakety) na infrastruktuře spolufinancované ze strukturálních fondů;

- zmínka o roli Evropské unie v dalších aktivitách jako jsou investice do výroby, vzdělávání atd.;

- možnosti informovat a publikovat koordinovaně s členskými státy, regiony a Komisí.

\section{Kontrola a prevence nedodržování pravidel}

Pro garanci úplnosti opatření financovaných ze strukturálních fondů je stanoveno, že členský stát bude provádět nezbytné kroky k ověření, že operace byly náležitě provedeny, bylo zabráněno nepravostem a byly nahrazeny částky, které se vyplýtvaly v důsledku nedodržování pravidel nebo nedbalosti.

Navíc musí členské státy informovat Komisi o kontrolním systému, který si vytvořily. Měly by pravidelně Komisi informovat o pokrocích v administrativních a zákonných postupech. Musí se také předložit Komisi příslušné národní kontrolní zprávy o opatřeních zahrnutých $\mathrm{v}$ programu.

Dále Komise může provádět kontrolu na místě, včetně namátkové kontroly, což se týká opatření financovaných ze strukturální fondů a management dotyčného členského státu podává hlášení s ohledem na obdrženou veškerou nezbytnou pomoc nebo bez hlášení, jestliže toto je zahrnuto ve smlouvě mezi Komisí a členským státem.

Komise může požadovat po členském státu, aby prováděl kontroly na místě k ověření správnosti platebních požadavků.

Dále nařízení Rady (ES) č. 1681/1994 z 11. července 1994 o nesrovnalostech a zpětném získání chybně vyplacených částek v souvislosti s realizací strukturálních politik a o organizaci informačního systému v této oblasti stanoví určitá opatření vztahující se $\mathrm{k}$ nepravostem a k navrácení nenáležitě vyplacených částek. Zvláště uvádí, že členský stát by měl informovat Komisi každé tři měsíce o jakýchkoli př́ípadech nesprávného použití př́spěvků ze strukturálních fondů přesahující 4000,- EUR a o krocích podniknutých pro vrácení těchto prostř̌edků. 


\section{Institucionální zajišstění v České republice}

Hlavní zásadou při využívání prostředků ze strukturálních fondů je přísné oddělení linií řídící (implementační), platební a kontrolní. Každý členský stát Evropské unie je povinen zrí́dit řídící a platební orgány, a to jak pro celkové řízení strukturální pomoci na národní úrovni, tak rovněž pro jednotlivé programy.

Řídící orgán má základní zodpovědnost za správnost řízení a realizaci operací strukturálních fondů. Řídícím orgánem pro Rámec podpory Společenství, který nese celkovou odpovědnost za účinnost, správnost řízení a provádění pomoci poskytované ze strukturálních fondů České republice, je Ministerstvo pro místní rozvoj. Mezi hlavní odpovědnosti řídícího orgánu patř́i zajistit informovanost veřejnosti o pomoci EU, organizovat výběr projektů vhodných $\mathrm{k}$ financování z prostředků EU, ověřovat spolufinancování, kontrolovat a schvalovat žádosti o platby, zajistit prevenci, odhalování a napravování nesrovnalostí, zavést a používat informační systém, předkládat podrobné zprávy o platbách konečným př́ijemcům, zavést a dodržovat systém auditu.

Platebním orgánem pro všechny operační programy (strukturální fondy) i Fond soudržnosti bylo určeno Ministerstvo financí - odbor Národního fondu. Platební orgán např̀. vypracovává a předkládá certifikované žádosti o platby Evropské komisi na základě reálně uskutečněných výdajů konečnými př́ijemci a přijímá platby z EU; zabezpečuje, aby konečný př́ijemce obdržel příspěvek z Evropské unie do 60 dnů po splnění všech podmínek; kontroluje uskutečněné výdaje; vrací neoprávněně vyplacené výdaje Evropské komisi a odevzdává zpět Evropské komisi nevyužité prostředky; vede evidenci o finančních prostředcích.

S cílem zajistit co nejefektivnější ř́zení pomoci ze strukturálních fondů byla výkonem funkcí řídících orgánů jmenována příslušná ministerstva (MMR, MPO, MZe, MŽP, MPSV). Některé funkce a aktivity budou platebním orgánem delegovány na tzv. platební jednotky zřizované na ministerstvech, které jsou řídícími orgány pro jednotlivé operační programy (organizačně odděleny od jednotek vykonávajících funkci řídícího orgánu).

Řídící orgány mohou část svých pravomocí delegovat na tzv. zprostředkující subjekt nebo také implementační agentury. Zprostředkujícím subjektem je veřejný nebo soukromý subjekt, který jedná v odpovědnosti řídících orgánů nebo provádí jejich jménem činnosti týkající se konečných př́ijemců. Je zpravidla zodpovědný za definování obsahu opatření a přípravu zásobníku projektů („project-pipeline“), nebở nejlépe zná potřeby konečného př́ijemce. Je rovněž zodpovědný za určitou část procesu hodnocení, výběr a monitorování spolufinancovaných projektů a zpracování osvědčení o výdajích, výroční zprávy či ověření způsobilosti údajů.

Konečnými př́ijemci podpory ze strukturálních fondů jsou veřejné nebo soukromé subjekty, které na základě předložené projektové žádosti pro pomoc prostřednictvím operačního programu obdrží finanční prostředky ze strukturálních fondů. V př́ípadě pomoci podle článku 87 Smlouvy o ES (podpory poskytované v jakékoliv formě státy nebo ze státních prostředků) a v př́ípadě pomoci poskytnuté orgány určenými členskými státy, jsou konečnými př́ijemci orgány, které pomoc poskytují. Koneční př́ijemci jsou odpovědní řídícímu orgánu za dodržení všech požadavků plynoucích z nařízení Rady (ES) č. 1260/1999 a navazujících opatření.

Konečný př́ijemce předkládá projekt, prokazuje zajištěné spolufinancování na realizaci projektu, odpovídá za realizaci projektu a za nakládání s prostř̌edky. Dále zodpovídá za dodržení základních principů EU. Koneční příjemci si musí být vědomi požadavků na 
publicitu (zajištuje regionální a místní publicitu o projektu), výběrová řízení a zpracování monitorovacích zpráv. Konečný př́ijemce předkládá žádosti o platby, je zodpovědný za předkládání pouze uznatelných nákladů a výdajů, které jsou v souladu se schválenými podmínkami projektu. Dále musí zajistit, že všechny nároky na platby jsou podloženy přijatými fakturami, výjimečně účetními dokumenty průkazné hodnoty. Koneční př́ijemci musí zajistit vedení dokumentace o projektech, která bude dostačující pomůckou pro audit se zaměřením na finanční toky ve smyslu čl. 7 nařízení Komise (ES) č. 438/2001 z 2. března 2001 (provádění čl. 38 nařízení Rady (ES) č. 1260/1999 - podrobná pravidla pro řídící a kontrolní systémy ohledně finančního řízení a finanční kontroly) ve znění nařízení Komise (ES) č. 2355/2002 z 27. prosince 2002.

Model systému výběru projektů

Uvažovaný koncept je zatím následující:

Pro účastníky výběrových řízení (předkladatelé projektů = investoři) připraví řídící orgán podrobné pokyny, které budou obsahovat nezbytné informace pro prredkladatele projektů, včetně doplňujících náležitostí (formulář, vysvětlivky, atd.). Bude stanoven termín sběru žádostí. Hlavní přílohou žádosti bude projekt.

Výběr projektů bude probíhat podle předem stanovených pravidel, která zahrnují následující kroky:

1. Řídící orgán/Zprostředkující subjekt vyhlásí projektové kolo a stanoví konečný termín pro odevzdání projektů. Předkladatelé vyplní projektovou přihlášku, která bude $\mathrm{k}$ dispozici u zprostředkujícího subjektu.

2. Zprostřredkující subjekt bude průběžně do ukončení kola přijímat a evidovat projektové přihlášky a následně provede formální kontrolu projektů. $V$ př́ípadě nejasností mohou zprostř̌edkující subjekty vznést upřesňující dotazy na předkladatele projektu. Po provedení kontroly jsou data o projektech vložena do Monitorovacího systému strukturálních fondů. Projekty nevyhovující formálním kritériím (neúplná dokumentace, nezpůsobilost výdajů, nesoulad s předpisy ČR a politikami ES aj.) budou vráceny zpět předkladatelům.

3. Z projektů vyhovujících formálním kritériím sestaví zprostředkovatelský subjekt seznam předložených projektů (tzv. „long-list“). Pro hodnocení projektů mohou být ustaveny hodnotitelské komise, které obdrží kopie předložených projektů a podpůrné materiály.

4. Projekty budou zevrubně posouzeny podle odbornosti př́ślušným outsourcingem ${ }^{6}$, a to v návaznosti na stanovená kritéria pro výběr projektů schválená monitorovacím výborem operačního programu, kritéria uvedená v operačním programu, resp. programovém dodatku, kvantifikované cíle opatření a směrnici řídícího orgánu pro hodnocení projektů, soulad s politikami ČR a Evropských společenství, způsobilost výdajů aj. Na základě bodového ohodnocení sestaví hodnotitelská komise návrh pořadí projektů vhodných k financování (tzv. „short-list“) a předloží je zprostředkujícímu subjektu k posouzení. Předkladatelé projektů mohou být během jednání hodnotitelské komise požádáni o doplnění dalších informací.

5. Zprostředkující subjekt připraví na základě bodového hodnocení všech hodnotitelských komisí souhrnný návrh výběru projektů příslušného kola výzvy a předloží jej na

6 Outsourcing představuje využití specializovaných subjektů pro specifické druhy odborné práce, které nelze zajištovatv rámci řídícího orgánu či zprostředkujícího subjektu. Outsourcing bude zajiš̌tovat servisní činnost pro řídící orgán a zprostředkující subjekt. 
jednání řídícího výboru př́ílušného operačního programu. Přílohou seznamu bude vyjádření hodnotitelské komise ke každému projektu; v návrhu budou uplatněny připomínky $\mathrm{k}$ nedostatkům výběru projektů, zejména pokud při výběru nebyly respektovány př́íslušné předpisy a směrnice, kvantifikované cíle opatření aj.; u projektů, které nebyly v daném kole vybrány bude vypracováno a předkladatelům zasláno zdůvodnění; aktualizují se data o výběru projektů v rámci monitorovacího systému.

6. Návrh dle předešlého bodu projedná řídící výbor, včetně kontroly zabezpečení spolufinancování projektů z veřejných zdrojů nebo jinými subjekty. Poté doporučí řídícímu orgánu seznam vybraných projektů ke schválení. Rídící orgán schválí seznam projektů, které budou podpořeny, včetně navrhované alokace prostředků na jednotlivé projekty.

7. Po projednání a potvrzení seznamu vybraných projektů řídícím orgánem připraví zprostředkující subjekt návrh smluv s konečným př́ijemcem podpory (podle standardního vzoru vydaného řídícím orgánem). Návrh předá př́ílušné výkonné jednotce, která provede formální kontrolu návrhu smlouvy s konečným př́ijemcem včetně posouzení velikosti příspěvku ze strukturálních fondů. Řídící orgán/Zprostředkující subjekt informuje předkladatele projektů o rozhodnutí řídícího orgánu. Součástí této informace bude i návrh smlouvy obsahující uvedení podmínek, za kterých je spolufinancování ze strukturálních fondů nabízeno.

8. Rozhodnutí o konečném výběru projektů včetně alokace prostředků na jednotlivé projekty přiijímá řídící orgán. Smlouvu podepisuje jménem řídícího orgánu vedoucí pracovník řídícího útvaru ministerstva a odpovědný zástupce konečného př́ijemce. Rídící orgán zasílá podepsané smlouvy konečným př́íjemcům a rovněž je předá pro informaci platební jednotce a současně je zašle i platebnímu orgánu. Výkonný útvar zprostředkujícího subjektu zajišluje informovanost o výběru projektů (tisk, webové stránky). Informace o podepsaných smlouvách jsou rrídícím orgánem nebo zprostředkujícím subjektem vloženy do monitorovacího systému programu.

\section{Současný stav přípravy na čerpání prostředků ze struktu- rálních fondů a příprava projektu}

Př́íprava na čerpání peněz z Evropské unie nabírala skluz. Evropská unie umožnila podávat projekty od počátku roku 2004, stát však neměl připraveny potřebné dokumenty. Chybělo stanovení kritérií výběru projektů s jejich bodováním. Rovněž nebylo přesně stanoveno, kolik prostředků bude moci žadatel získat ze strukturálních fondů a kolik si bude muset opatřit sám. Výše podpory ze strany EU se liší podle priority/opatření, žadatele, jeho sídla a typu projektu (bude-li projekt přinášet zisk, bude výše podpory nižší a naopak). Její mezní výše je stanovena procentem uznatelných nákladů projektu. Ty jsou jasně specifikovány. $\mathrm{V}$ některých případech mohou zahrnovat i prrípravu projektové či další podkladové dokumentace. $\mathrm{V}$ určitých případech může být poskytována rovněž podpora $\mathrm{z}$ veřejných zdrojů - v závislosti na množství prostředkủ vyčleněných pro spolufinancování příslušného opatření v daném roce.

Na jednotlivých ministerstvech probíhají přípravy tzv. programových dodatků a příslušných manuálů, které stanoví podmínky a postupy realizace, typy možných projektů, kritéria výběru, okruh konečných př́ijemcủ apod. S ohledem na skutečnost, že několik týdnů před naším vstupem do Evropské unie nebyly zveřejněny konečné verze operačních programů či jednotných programových dokumentů, zpozdil se tak celý proces vyhlášení 
jednotlivých programů. Česká republika proto asi v prvních měsících členství v EU z fondů Evropské unie př́liš peněz nezíská.

Přesto je zapotřebí započít s přípravou kvalitních projektů co nejdříve. Před započetím př́íprav na projektu, $\mathrm{k}$ jehož realizaci hodlá žadatel čerpat finanční prostředky poskytované ze strukturálních fondů $\mathrm{EU}$, je třeba mít na paměti několik důležitých pravidel a zásad.

V první řadě je nutné upozornit na to, že cílem strukturálních fondů je poskytnutí podpory pouze pro činnosti, které budou životaschopné rovněž po skončení finanční pomoci ze strukturálních fondů Evropské unie. $Z$ tohoto důvodu není možné žádat o proplácení běžných výdajů spojených s fungováním instituce žadatele. Obdobný problém nastane u organizací, které chtějí připravovat projekty jen z toho důvodu, že Evropská unie nabízí podporu. Na takovýchto projektech je mnohdy vidět, že jsou připravovány s cílem, aby prošly výběrovým řízením a samotná proveditelnost projektu bývá slabší stránkou. U těchto projektů žadatelé o dlouhodobé udržitelnosti mnohdy vůbec neuvažují. Je však dost možné, že právě na takové projekty se zaměří kontrola ze strany Evropské komise, která bude sledovat efektivnost vynaložených prostředků.

Žadatelé o podporu ze strukturálních fondů musejí být připraveni na to, že pomoc ze strukturálních fondů Evropské unie nebude poskytována kterémukoliv projektu, ale že pomoc bude směrována tam, kde žadatel doloží smysluplný záměr, jehož realizace bude skutečným přínosem nejen pro něj, ale rovněž i pro jeho okolí, a že takovýto projekt bude z peněz Evropské unie proplacen teprve v momentě, kdy se prokáže, že byl skutečně zrealizován a nezůstal pouze na papíre. Tento př́stup vyžaduje od žadatelů mít nejen jasnou představu o př́nosu projektu navrženého $\mathrm{k}$ podpoře ze strukturálních fondů, ale také o jeho financování. A to jak v podobě financování projektu z vlastních prostředků až do doby, kdy je možno žádat o proplacení skutečně vynaložených a uznatelných nákladů (v některých př́ípadech se jedná o zálohování celého projektu), ale rovněž o zajištění spolufinancování z jiných zdrojů než zdrojů Evropské unie.

Žadatel si musí předem ověrit, jak velkou část celkových oprávněných nákladů projektu je možné maximálně nárokovat k financování ze zdrojů Evropské unie. Je třeba zvážit vlastní finanční a ekonomickou situaci a reálně stanovit možnosti vlastního financování. Vnějšími zdroji mimo prostř̌edků ze strukturálních fondů Evropské unie mohou být dotace, podpory, záruky, apod. Zapomenout by se nemělo ani na možnost čerpání úvěrů. Zejména u soukromých finančních prostředků je zapotřebí doložit jejich zajištění.

Analýzu nákladů a výnosů, plánované toky finančních prostředků, zdrojů financování obsahuje finanční plán. Navrhovaný způsob financování a spolufinancování se realizuje formou finanční tabulky, která tvoří povinnou součást projektu a vyjadřuje objemy finančních prostředků z jednotlivých zdrojů ( $\mathrm{z}$ tabulky by mělo být patrno, kolik prostředků poskytne EU, kolik bude z domácích veřejných zdrojů a kolik ze soukromých). Finanční prostředky mohou být složeny z veřejných i soukromých prostředků od více partnerů, kteří se $\mathrm{v}$ duchu principu partnerství budou na řešení podílet.

Náklady hrají v projektu významnou roli. Nereálně sestavený rozpočet se odrazí při hodnocení projektu. Příliš vysoké náklady v poměru k výstupům a efektům/přínosům projektu mohou být důvodem zamítnutí projektu.

V rámci strukturálních fondů mají přednost ty projekty, které zahrnují rozvoj území jako celku, řeší komplexní problémy venkovského obyvatelstva, jeho ekonomickou a sociální stabilitu, ochranu životního prostředí apod. a podle toho zajištujíi potřebnou účast partnerů v projektu. Větší naději na podporu ze strukturálních fondů Evropské unie mají 
projekty umístěné mimo ekonomická centra, nebot Evropská unie věnuje zvláštní pozornost rozvoji venkovských či méně rozvinutých oblastí.

Na počátku každého projektu musí stát jasný záměr a co nejkonkrétnější představa o jeho realizaci. Projekt je oprávněný získat finanční pomoc ze strukturálních fondů Evropské unie, shodují-li se jeho cíle s prioritními cíli aktuálních víceletých programů pro daný strukturální fond a mají-li tyto cíle oporu v rozvojových dokumentech - operačních programech a Jednotném programovém dokumentu. Tato zásada vychází z principu programování.

Jasný, výstižně popsaný záměr, jeho srozumitelná formulace a konkrétní, kvantifikovatelný, věcně a časově kontrolovatelný cíl jsou předpokladem úspěšného přijetí projektu i pro jeho samotnou realizaci. Ve všech případech je nezbytné prokázat životaschopnost projektu. Návrh projektu musí splňovat velmi přísná kritéria na přehlednost, jasnost (vyvarujte se použití př́liš častého a pro laiky nesrozumitelného odborného slangu), srozumitelnost a přesvědčivost. Atraktivní a jasná prezentace projektu vysoce zvyšuje pravděpodobnost úspěchu mezi stovkami dalších zájemců. Přípravě projektu je zapotřebí věnovat vždy dostatek času a prostředků.

Předpokladem úspěšného vypracování projektu je důkladné pročtení si zadávací dokumentace, zejména finanční části projektu a finančního plnění. Důležité je rovněž ověření shody záměru projektu a jeho klíčových parametrů s prioritními cíli programů realizovaných v rámci strukturálních fondů. Jistou nápovědou pro předkladatele projektů je hodnotící systém př́slušného projektu, podle kterého lze vysledovat, jaké části žádosti mohou být zásadní v „př́ínosu bodư “ při hodnocení projektu. Na druhou stranu není vhodné psát projekt jen za účelem získání finanční podpory. Na příkladech mnoha projektů lze říci, že je-li předkladatel veden snahou získat finanční podporu a samotné téma je pro něj až druhořadé, na projektu se to projeví. Častým nešvarem je zdůvodňování projektu doslovným opisem zdůvodnění programu, do kterého je projekt předkládán. $\mathrm{V}$ takovém případě se obvykle hodnocený projekt nesetká s vysokým hodnocením.

$\mathrm{Z}$ tohoto pohledu je vhodné mít představu o záměru, který chcete realizovat a $\mathrm{k}$ němu přiřazovat finanční zdroje, které jej budou financovat. Nemusí vždy jít pouze o strukturální fondy, ale může jít o kombinaci rủzných zdrojů (viz výše).

Lhůta pro podání projektu (časový limit od vyhlášení výběrového řízení do jeho uzavření), kdy musí být projekt představen, je obvykle příliš krátká. Je však nezbytné ji dodržet. Je proto vhodné začít shromažd’ovatveškeré nezbytné informace, kontaktovat partnery a pracovat na projektu již tehdy, kdy je program vyhlášen a nečekat až na moment, kdy je zveřejněno výběrové řízení. Ostatně v současné době již běží př́ípravné práce na mnoha projektech u organizací, které mají jasné projektové záměry a plánují, že k jejich realizaci využijí i pomoci ze strany strukturálních fondů.

Předpokladem úspěchu projektu je rovněž jasná a srozumitelná forma návrhu. Rovněž úprava dokumentu musí být přehledná a jasná. Je zapotřebí klást maximální důraz na kvalitu argumentace při zdůvodňování výběru projektu.

Pro žádosti o spolufinancování je používána jednotná forma. V žádosti musí žadatel prokázat oprávněnost cílů projektu a svou způsobilost realizovat projekt, popsat projekt prostřednictvím indikátorů ve vztahu k jednotlivým cílovým skupinám a rozpracovat rozpočet projektu a rozbor jednotlivých nákladů. Pečlivé vypracování žádosti je předpokladem úspěšnosti projektu. 


\section{Literatura}

1. TiChý, L. - ARNOLD, R. - SVOBODA, P. - ZEMÁNEK, J. - KRÁL, R.: Evropské právo. 1. vydání. Praha, C.H.Beck 1999.

2. TICHÝ, L. a kol.: Dokumenty ke studiu evropského práva. Praha. Linde, 1999.

3. POTLUKA, O. a kolektiv: Průvodce strukturálními fondy Evropské unie. 1. vydání. Praha, IREAS, Institut pro strukturální politiku, o. p. s. 2003.

4. WAWROSZ, P. - SLOVÁČKOVÁ, P.: Průvodce podnikatele právem Evropského společenství. Praha, Rada vlády ČR pro sociální a ekonomickou strategii, 2002.

5. Evropská unie regionům, Praha. Delegace Evropské komise v České republice, 2002.

6. Nařízení (ES) Evropského parlamentu a Rady č. 1783/1999 ze dne 12. července 1999 o Evropském fondu pro regionální rozvoj.

7. Nařízení (ES) Evropského parlamentu a Rady č. 1784/1999 ze dne 12. července 1999 o Evropském sociálním fondu.

8. Nařízení Rady (ES) č. 1257/1999 z 17. května 1999 o podpoře rozvoje venkova z Evropského zemědělského podpůrného a záručního fondu (EAGGF) ve znění pozdějších změn a doplňků.

9. Nařízení Rady (ES) č. 1263/1999 z 21. června 1999 o Finančním instrumentu pro řízení rybolovu.

10. Nařízení Rady (ES) č. 1260/1999 z 21. června 1999 o obecných ustanoveních o strukturálních fondech.

11. Nařízení Rady (ES) č. 1681/1994 z 11. července 1994 o nesrovnalostech a zpětném získání chybně vyplacených částek v souvislosti s realizací strukturálních politik a o organizaci informačního systému $\mathrm{v}$ této oblasti.

12. Nařízení Komise (ES) č. 448/2004 z 10. března 2004, kterým se mění nařízení (ES) č. 1685/2000 upravující podrobná pravidla pro implementaci nařízení Rady (ES) č. 1260/1999 - způsobilost výdajů na činnosti spolufinancované strukturálními fondy a které ruší Nařízení (ES) č. 1145/2003.

13. Nařízení Komise (ES) č. 438/2001 z 2. března 2001 (provádění čl. 38 nařízení Rady (ES) č. 1260/1999 - podrobná pravidla pro řídící a kontrolní systémy ohledně finančního řízení a finanční kontroly) změněno nařízením Komise (ES) č. 2355/2002 z 27. prosince 2002.

14. Internetové stránky Evropské unie www.europa.eu.int. 